\title{
Synthesis of N-benzothiazole derivative imide on polymeric chain, have possible biological activity
}

\author{
Entesar O.AL-Tamimi* , Mohmoud A-AL-Issa ${ }^{* *}$ \\ Hind F-AL-Gburi**
}

Received 17, September, 2012

Accepted 9, December, 2012

\begin{abstract}
:
In this reserch Some new substituted and unsubstituted poly imides compounds. were synthesized by reaction of acrylol chloride with different amides (aliphatic and aromatic) in a suitable solvent in the presence amount triethyl amine $\left(\mathrm{Et}_{3} \mathrm{~N}\right)$ with heating. The Structure confirmation of all polymers were confirmed using FT-IR, ${ }^{1} \mathrm{H}$ $\mathrm{NMR},{ }^{13} \mathrm{C}-\mathrm{NMR}$ and UV spectroscopy. Thermal analysis (TG) for some polymers showed their thermal stabilities. Other physical properties including softening points, melting point and solubility of the polymers were also measured
\end{abstract}

Key word:2-aminobenzothaizol,acrylol chloride.

\section{Introduction}

A heterocyclic compound is one which possesses a cyclic structure with at least two different kinds of hetero atoms in the ring. Nitrogen, oxygen and sulphur are the most common hetero atoms. Benzothiazole is a heterocyclic compound, weak base, having varied biological activities and still of great Scientific interest nowa days. They are widely found in bioorganic and medicinal chemistry with application in drug discovery[1]. Benzothiazole moieties are part of compounds showing numbering biological activities such as antimicrobial [2-6], anticancer [7-11], antilmintic and anti-diabetic activities. Polyimides have been widely used as high temperature insulators and dielectrics, coatings, adhesives and materials in a variety of advanced technologies related to microelectronics, where miniaturization and large-scal integration are important technical issues [13-14]. Then high thermal stability and balanced mechanical and electrical properties [15-17]. Polyimides are mainly used in the aerospace and electronics industries in the form of film and mouldings, but high melting point and insolubility in organic solvent limited their [18-20], application. furthermore,few successful attempts have been made to convert or modify some specific $\mathrm{N}$ substituted imide to serve as ion exchange resins, such as cross linked poly[N-phenyl maleimide] which was prepared by free radical polymerization of the corresponding imide in benzene. The precipitated polyimides were hydrolyzed to obtain some pendant carboxylic groups on the polymeric chains. The last compounds were found to be useful cationic [21] exchange resins of good capacities.

\section{Materals and Methods}

\section{General}

1. Melting points were recorded by using Gallen Kamp MFB-600 capillary melting point apparatus.

2. FT-IR spectra were recorded using solid $\mathrm{KBr}$ discs by testing

\footnotetext{
*Department of Chemistry, College of Science, University of Baghdad, Iraq

** Department of Chemistry, College of Science for Woman, University of 
Shimadzu FT-IR 8000 series

Fourier transform, infrared spectrophotometer.

3. Thermal analyses were performed using thermal analysis system consisting from $\mathrm{TG}_{50}$ Shimadzu, Japan. Ibn Sina in Iraq.

4. ${ }^{1} \mathrm{H}-\mathrm{NMR}$ and ${ }^{13} \mathrm{C}-\mathrm{NMR}$ spectra.

Company Bruker, model ultra shield $300 \mathrm{MHz}$, were made at the Chemistry Department, Al-Albyt University, Jordan.

\section{Preparation of 2-}

\section{aminobenzothiazole Derivatives[22,} 23]

In a $250 \mathrm{ml}$ round bottomed flask equipped with a magnetic bar stirrer and dropping funnel, a solution of bromine $(1.2 \mathrm{ml})$ in glacial acetic acid $(75 \mathrm{ml})$ was allowed to run through the dropping funnel drop wise during $30 \mathrm{~min}$. To a mixture of Para substituted aromatic amine $(0.03 \mathrm{~mol})$ and ammonium thiocyanate $(0.1 \mathrm{~mol})$ in $150 \mathrm{ml}$ glacial acetic acid with stirring. The mixture was stirred for 1 hr., then diluted with water and neutralized with solid sodium hydroxide. The precipitated substance was filtered, triturated and recrystallized from a suitable solvent to obtain 2-amino benzothiazole derivatives. The physical properties of the synthesized compounds are given in Table (1).
2. General Procedure Preparation of 2-[N-(sub or unsub benzoyl and sub or unsub acetyl)amidyl sub benzothiazole]

In a round bottom flask equipped with a magnetic bar stirrer and reflux condenser was placed a mixture of sub-benzoyl chloride $(0.06$ $\mathrm{mol})$ and $(0.06 \mathrm{~mol})$ 6-sub-2aminobenzothiazole with (3) drops of triethyl amine $\left(\mathrm{Et}_{3} \mathrm{~N}\right)$ in $(25 \mathrm{ml})$ of suitable solvent (Benzene) and refluxed (1-3) hrs after the solvent was removed and from ethanol.

3. General Procedure Preparation of Poly 2-(N-acryl-N-sub or unsub benzoyl) imidyl Substituted Benzothiazole

In a round bottom flask equipped with a magnetic bar stirrer was placed a mixture of poly (acryloyl chloride) (0.06 mol) and (0.06 mol) of 2-N-sub amidyl-sub benzothiazole with $(1 \mathrm{ml})$ of triethyl amine $\left(\mathrm{Et}_{3} \mathrm{~N}\right)$ in $(25 \mathrm{ml})$ of suitable solvent (THF or DMF) and refluxed for (5-7) hrs. after cooling and removed the solvent. The solid separated was filtered and purified by dissolving at DMF or DMSO and re precipitating from water or acetone. This procedure was applied on compounds as shown in Table (1). All physical properties are listed in Table (1).

\section{Results and Discussion}

Preparation of [2-(N-benzoyl) amidyl sub benzothiazole]

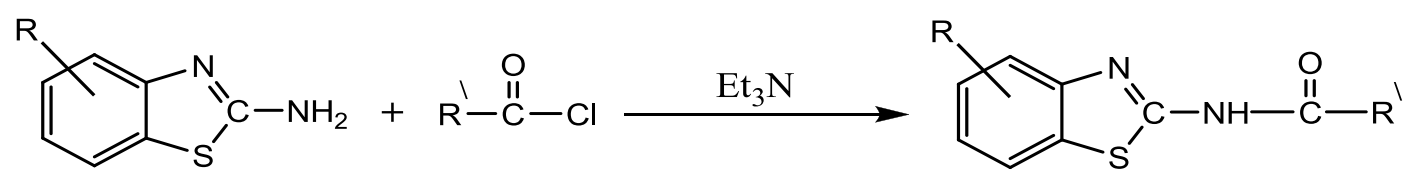

$\mathrm{R}=\mathrm{CH}_{3}, \mathrm{NO}_{2}, \mathrm{Cl}$<smiles>[R]C(=[X])c1ccccc1-c1ccccc1Cl</smiles> 
All poly [2-(N-acryl-N-benzoyl) imidyl substituted benzothiazole. were prepared by the reaction of poly (acryloyl chloride) with different amides . in presence<smiles>[R]CC(=O)N(c1nc2cc([R])ccc2s1)c1nc2c([R])cccc2s1</smiles>

of triethyl amine $\left(\mathrm{Et}_{3} \mathrm{~N}\right)$ as a catalyst [24].All these compounds characterised by (FT.IR,UV, and softing point), Table(1).
The mechanism of reaction involves a nucleophilic attack on the carbonyl as shown below [25].

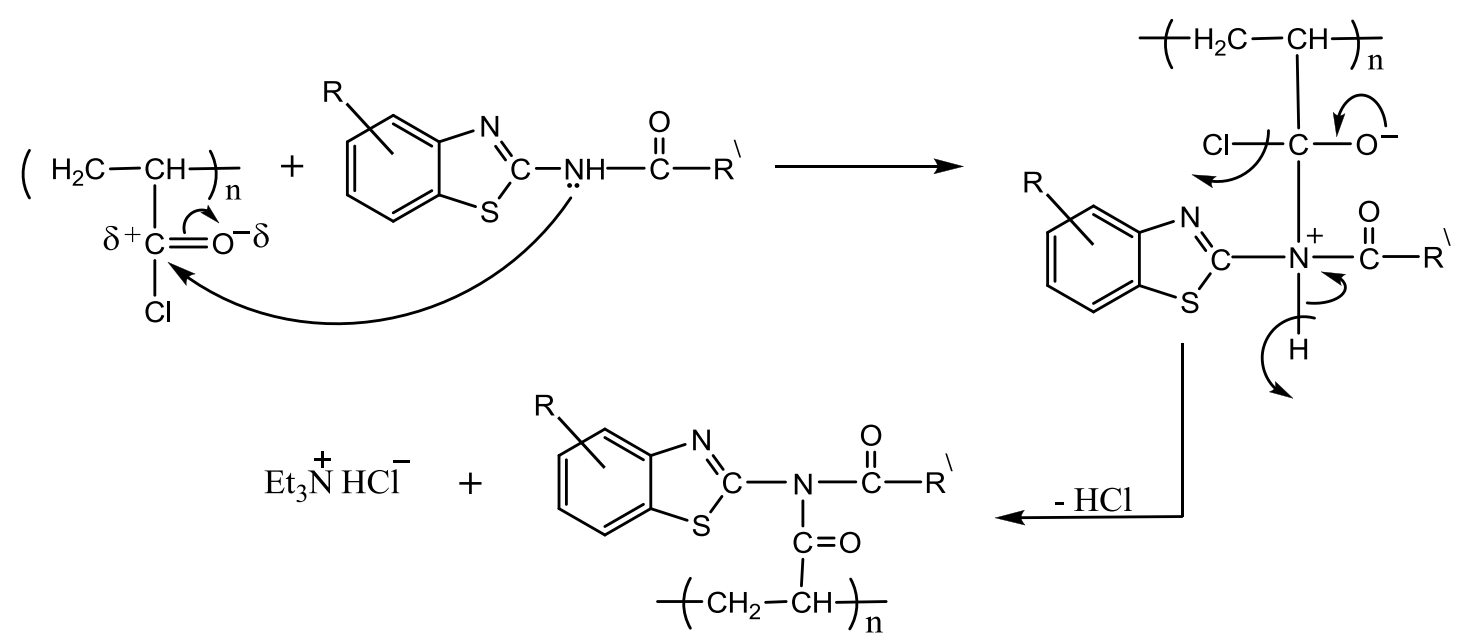

Structures confirmation of all prepared polymer proved using FT-IR, UV, $\quad{ }^{1} \mathrm{H}-\mathrm{NMR},{ }^{13} \mathrm{C}-\mathrm{NMR}$, TG and physical properties including softening point, solubility, $\mathrm{Tg}$ and percent conversion of the polymers. FT-IR spectrum of compounds showed the same bands appearance. Stretching band at $1670 \mathrm{~cm}^{-1} \quad v(\mathrm{C}=\mathrm{O}), \quad(2800$ 2920) $\mathrm{cm}^{-1} \quad v(\mathrm{C}-\mathrm{H})$ aliphatic, (15901630) $\mathrm{cm}^{-1} \quad v(\mathrm{C}=\mathrm{C})$ and (3010$3100) \mathrm{cm}^{-1} v(\mathrm{C}-\mathrm{H})$ aromatic as shown Table (2). ${ }^{1} \mathrm{H}-\mathrm{NMR}$ spectrum of polymers $[3,4,5]$ showed the signals at $\delta(1.2)(\mathrm{t}, 2 \mathrm{H}, \quad), \delta(3.1)(\mathrm{m}$, $1 \mathrm{H}, \quad)$ while a signal at $\delta(7-$ 8) (d or $\mathrm{m}, 1 \mathrm{H}, \mathrm{Ph}-\underline{\mathrm{H}})$ and $\delta 1.02$ $\left(\mathrm{s}, 3 \mathrm{H}, \mathrm{Ph}-\mathrm{CH}_{3}\right)$, as shown listed in Table (3).

The ${ }^{13} \mathrm{C}-\mathrm{NMR}$ spectrum of compound showed the signal at (170-180)ppm for carbonyl group $(\mathrm{C}=\mathrm{O})$ and appeared at (120-140)ppm and appeared at (20-50.48)ppm. UV spectrum of compounds absorption $\lambda_{\max }$ at $300 \mathrm{~nm}$ and $380 \mathrm{~nm}$ which attributed to $\left(\pi \rightarrow \pi^{*}\right)$ and $\left(\mathrm{n} \rightarrow \pi^{*}\right)$ transitions. See Table (4). TG analysis provides a change in the mass of the polymer during heating. The thermal analysis was carried out at temperatures $(200-400)^{\circ} \mathrm{C}$ with heating rate $20.0{ }^{\circ} \mathrm{C} / \mathrm{min}$. in $\mathrm{N}_{2}$ atmosphere. Thermal stability of the product was estimated from TG and DTG thermograms. See Table (5), it was found that the prepared polymers high stability, resists to isomerization by 
heat, light or using acidic or basic solution[26,27].

Table (1): Physical properties of the poly imide

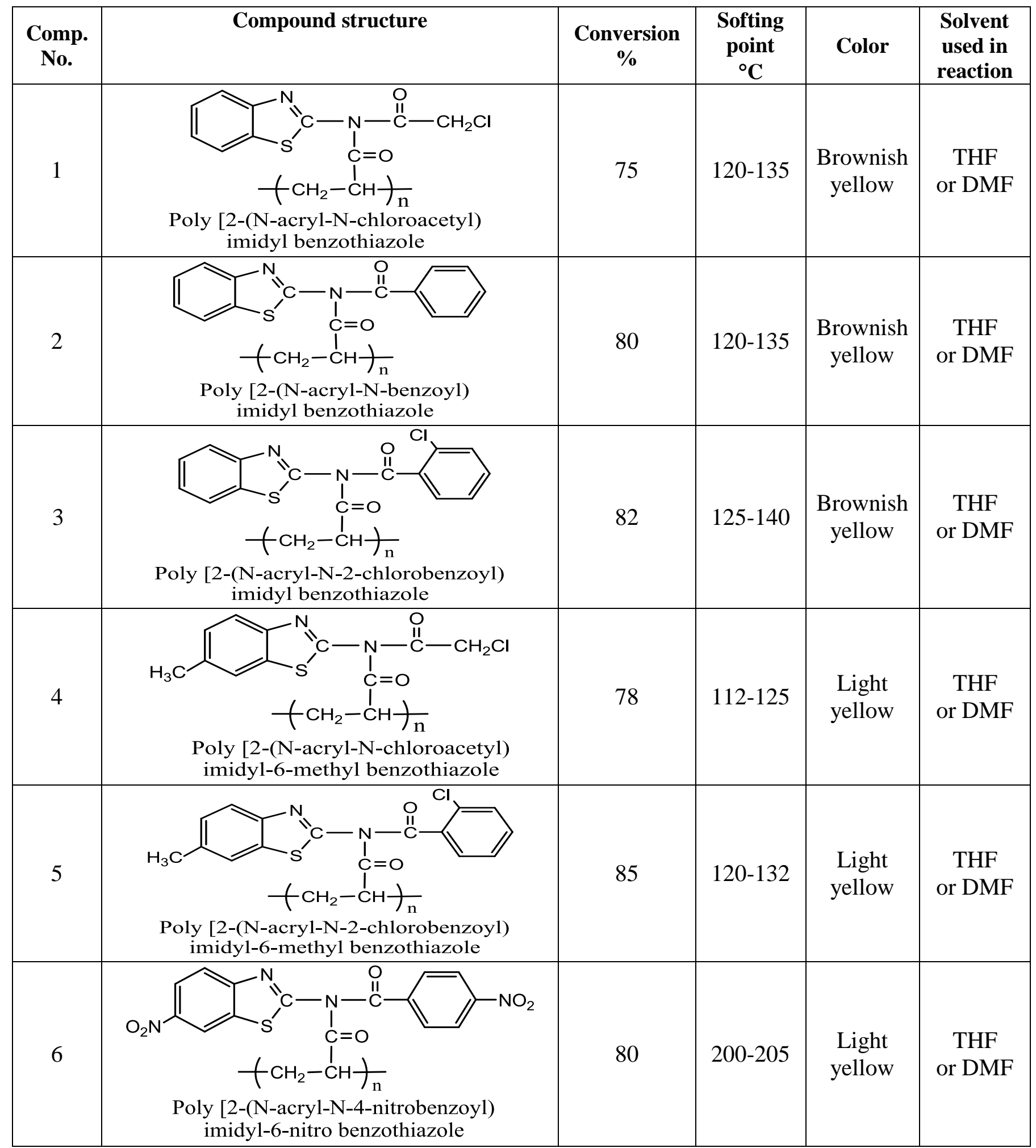




\begin{tabular}{|c|c|c|c|c|c|}
\hline 7 & $\begin{array}{c}\mathrm{s}^{\prime} \quad \stackrel{1}{\mathrm{C}}=\mathrm{O} \\
\left(\mathrm{CH}_{2}-\mathrm{C}-\mathrm{C}\right)_{\mathrm{n}} \\
\text { Poly [2-(N-acryl-N-acetyl) } \\
\text { imidyl-4,6-di-chloro benzothiazole }\end{array}$ & 78 & $85-100$ & $\begin{array}{l}\text { Light } \\
\text { yellow }\end{array}$ & $\begin{array}{c}\text { THF } \\
\text { or DMF }\end{array}$ \\
\hline $\begin{array}{c}\text { Comp. } \\
\text { No. }\end{array}$ & Compound structure & $\begin{array}{c}\text { Conversion } \\
\%\end{array}$ & $\begin{array}{c}\text { Softing } \\
\text { point } \\
{ }^{\circ} \mathbf{C}\end{array}$ & Color & $\begin{array}{l}\text { Solvent } \\
\text { used in } \\
\text { reaction }\end{array}$ \\
\hline 8 & 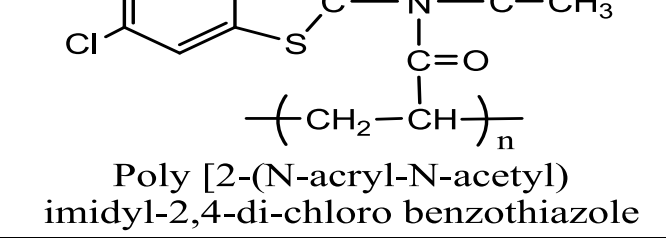 & 70 & $170-180$ & $\begin{array}{l}\text { Light } \\
\text { yellow }\end{array}$ & $\begin{array}{c}\text { THF } \\
\text { or DMF }\end{array}$ \\
\hline 9 & $\begin{array}{c}\quad \mathrm{C}=\mathrm{O} \\
\left(\mathrm{CH}_{2}-\mathrm{CH}\right)_{\mathrm{n}} \\
\begin{array}{l}\text { Poly [2-(N-acryl-N-benzoyl)imidyl } \\
\text {-4-nitro-6-chloro benzothiazole }\end{array}\end{array}$ & 85 & $95-105$ & Brown & $\begin{array}{c}\text { THF } \\
\text { or DMF }\end{array}$ \\
\hline 10 & $\begin{array}{c}\left.+\mathrm{CH}_{2}-\mathrm{CH}\right)_{\mathrm{n}} \\
\text { Poly [2-(N-acryl-N-acetyl) } \\
\text { imidyl-6-chloro benzothiazole }\end{array}$ & 87 & $125-142$ & Brown & $\begin{array}{c}\text { THF } \\
\text { or DMF }\end{array}$ \\
\hline 11 & $\begin{array}{c}\mathrm{S} \quad \mathrm{C}=\mathrm{O} \\
\left.+\mathrm{CH}_{2}-\mathrm{CH}\right)_{\mathrm{n}} \\
\begin{array}{c}\text { Poly [2-(N-acryl-N-2-mercaptobenzoyl) } \\
\text { imidyl-6-chloro benzothiazole }\end{array}\end{array}$ & 85 & $170-180$ & Brown & $\begin{array}{c}\text { THF } \\
\text { or DMF }\end{array}$ \\
\hline 12 & 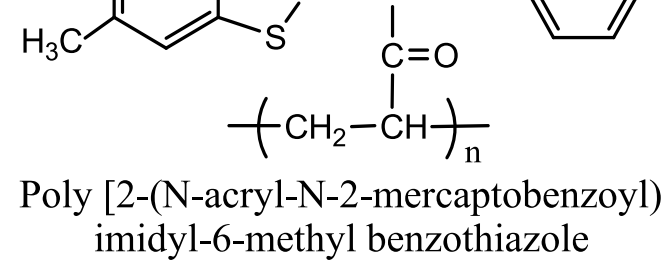 & 82 & $130-140$ & $\begin{array}{l}\text { Light } \\
\text { yellow }\end{array}$ & $\begin{array}{c}\text { THF } \\
\text { or DMF }\end{array}$ \\
\hline
\end{tabular}


Table (2): FT-IR spectra of the prepared heterocyclic polyimide

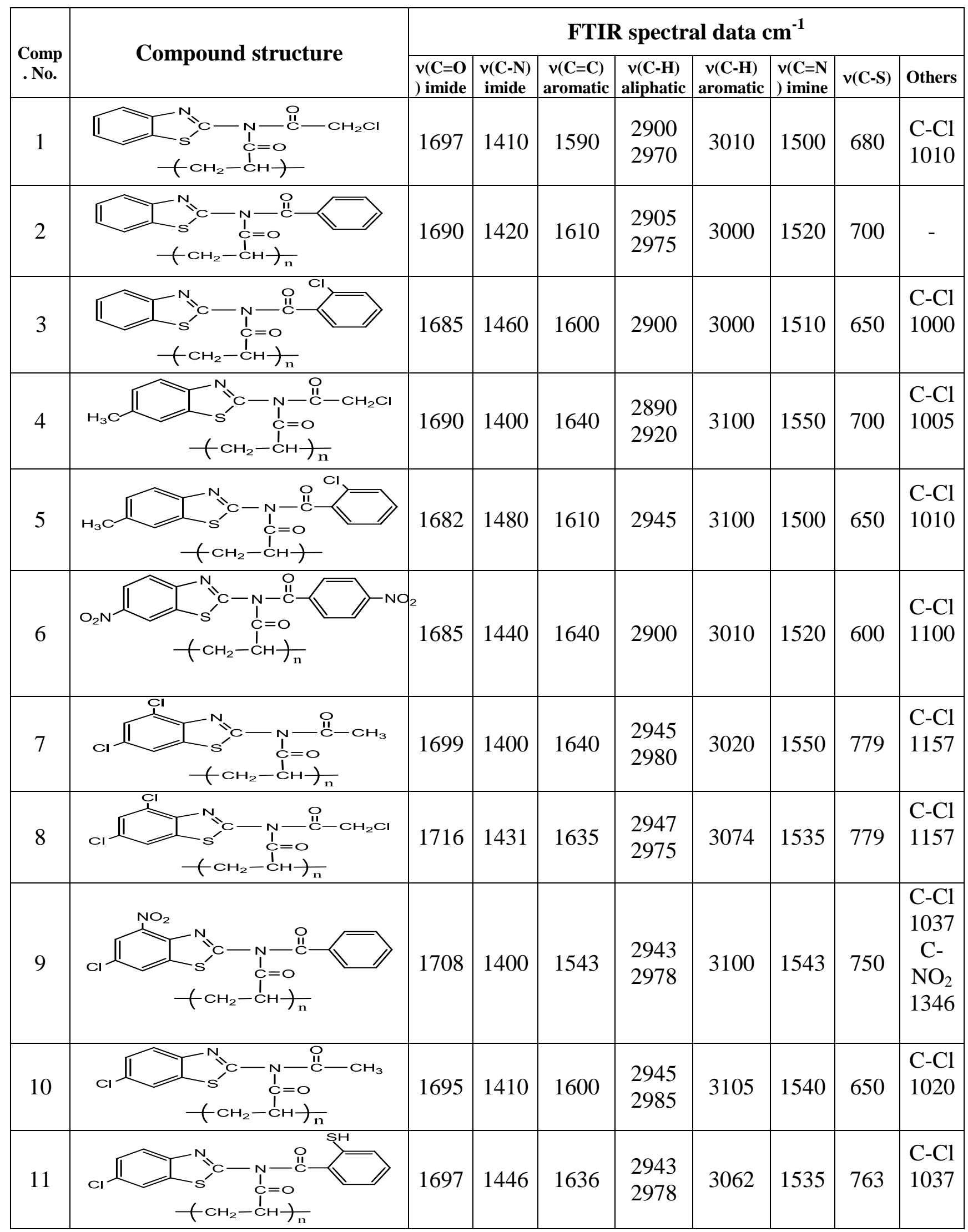




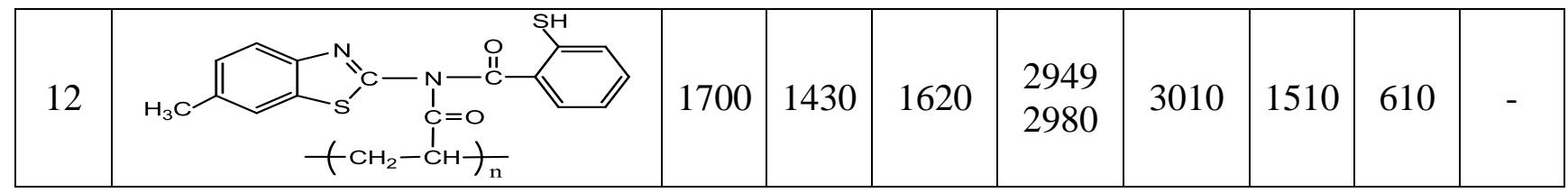

Table (3): The ${ }^{1} \mathrm{H}$-NMR chemical shifts of some of the prepared poly heterocyclic imides

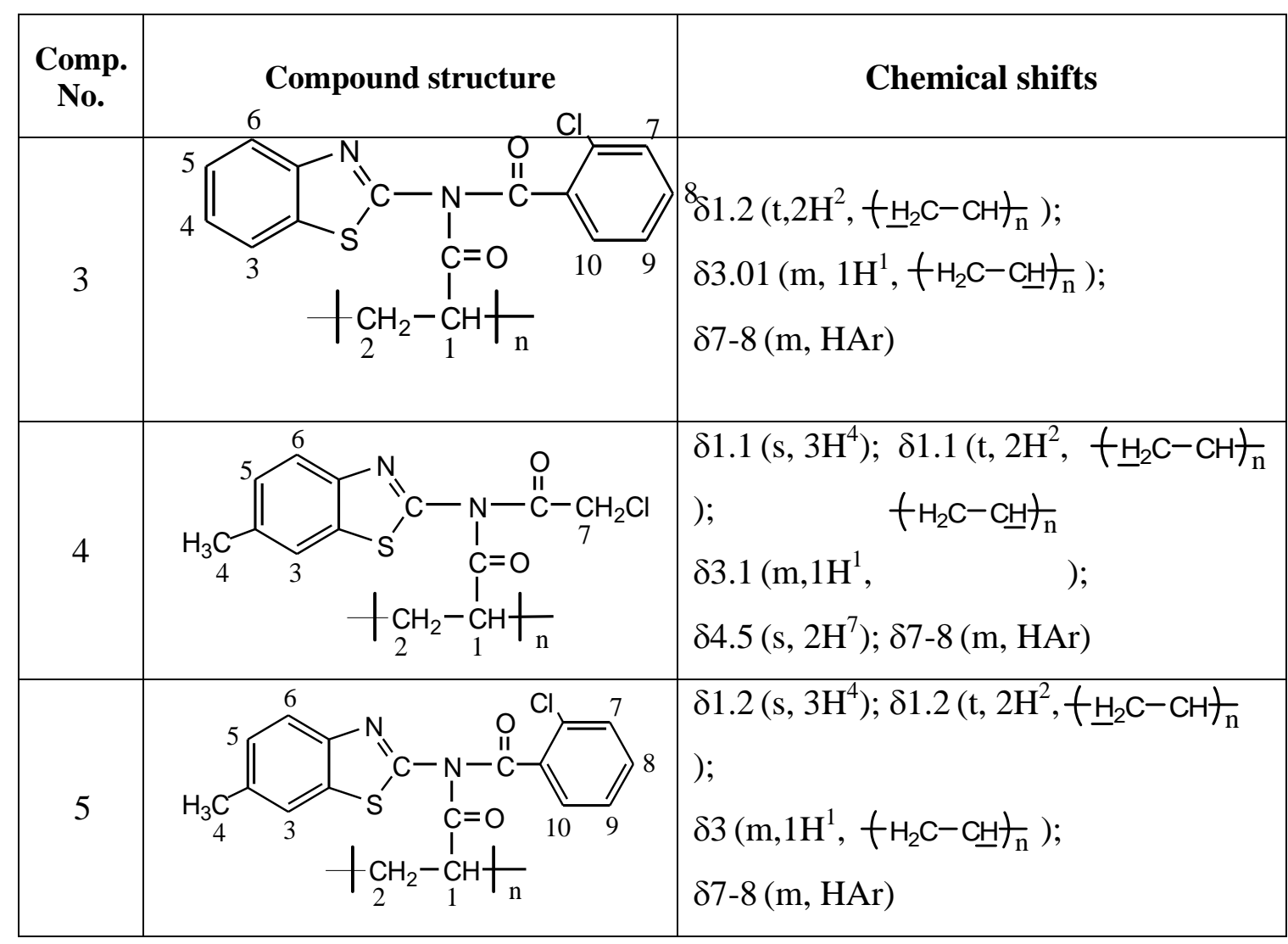

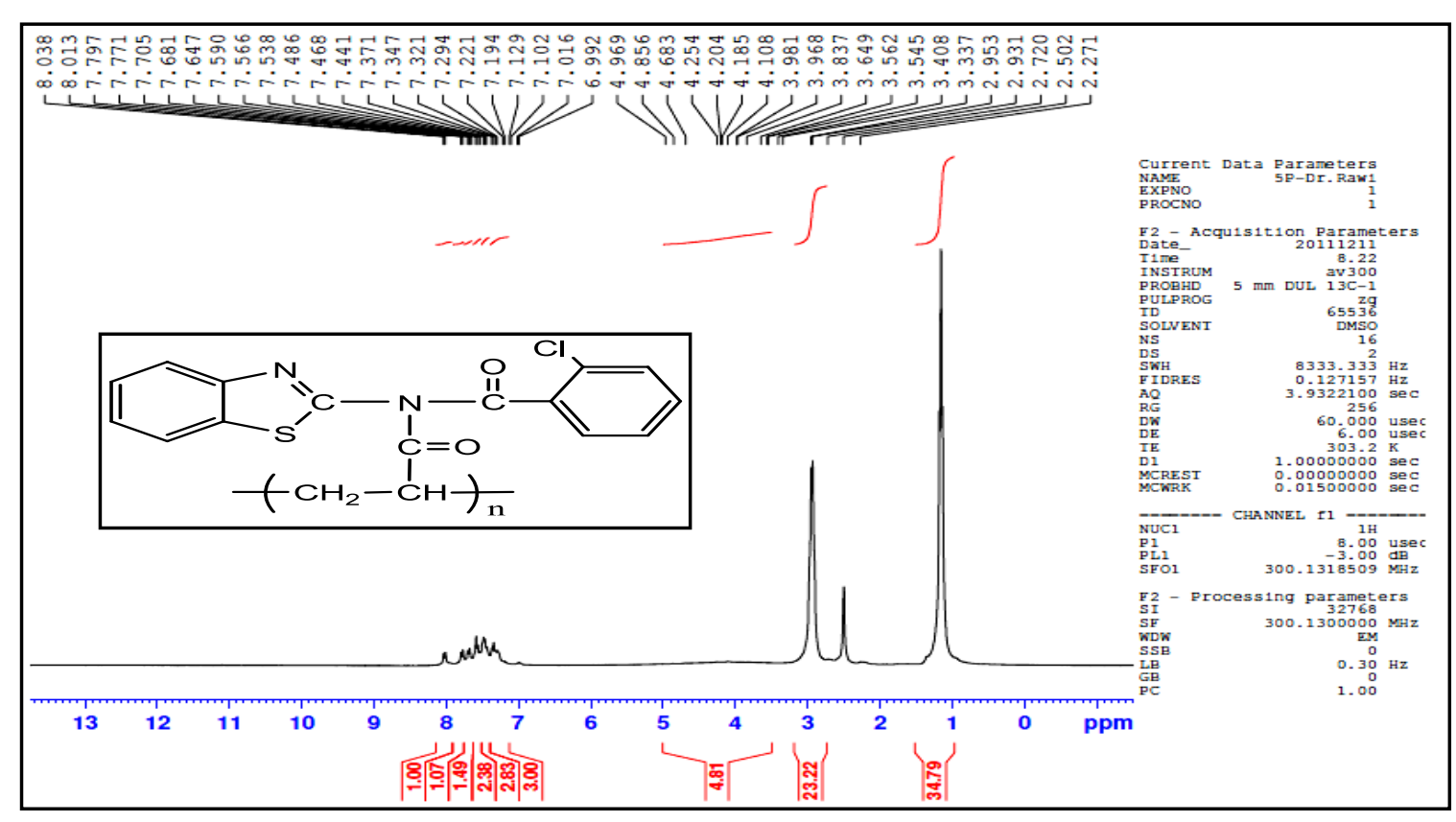

Fig.(1): ${ }^{1} \mathrm{H}-\mathrm{NMR}$ for compound[3] 


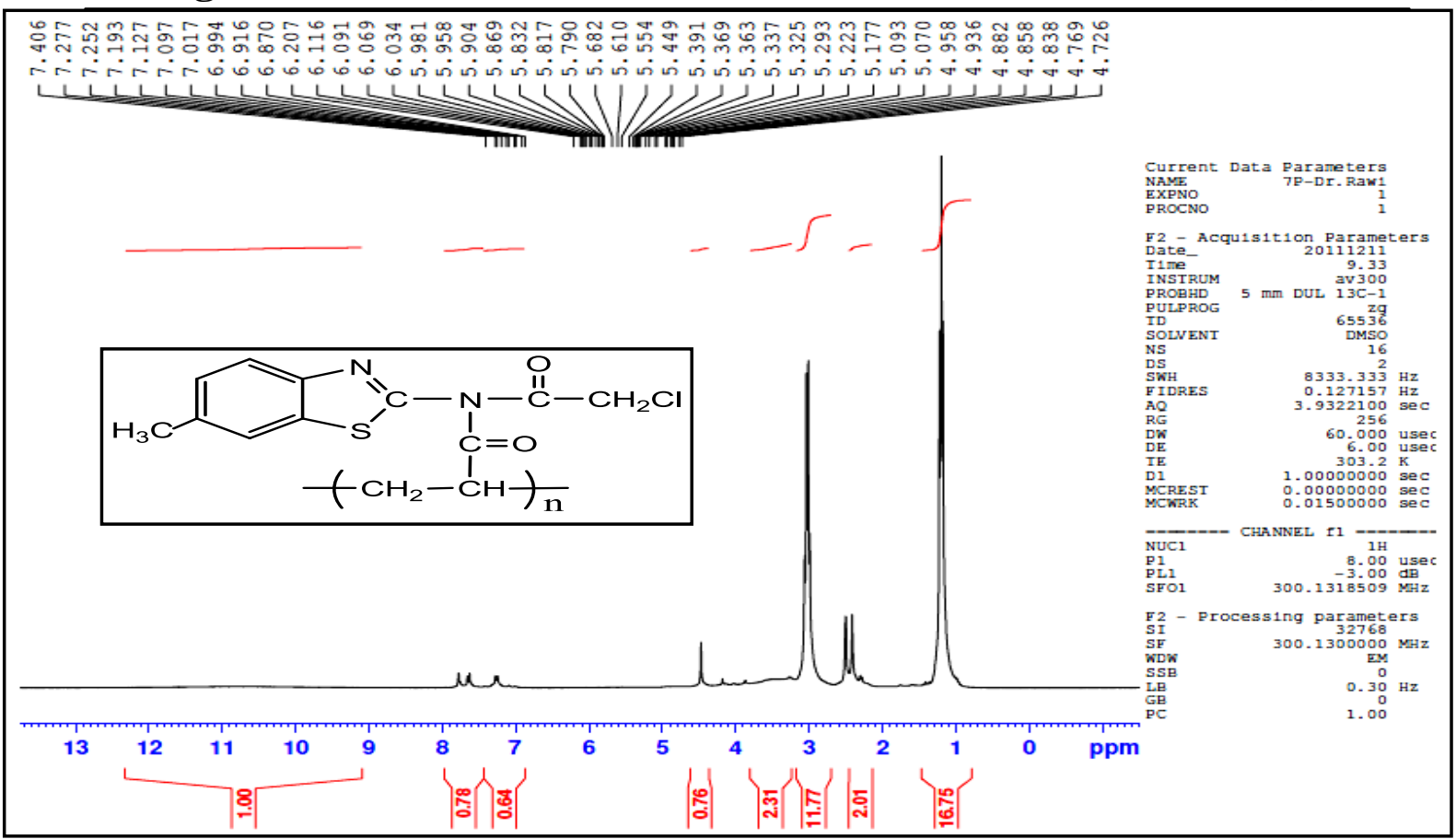

Fig.(2): ${ }^{1} \mathrm{H}-\mathrm{NMR}$ for compound[4]

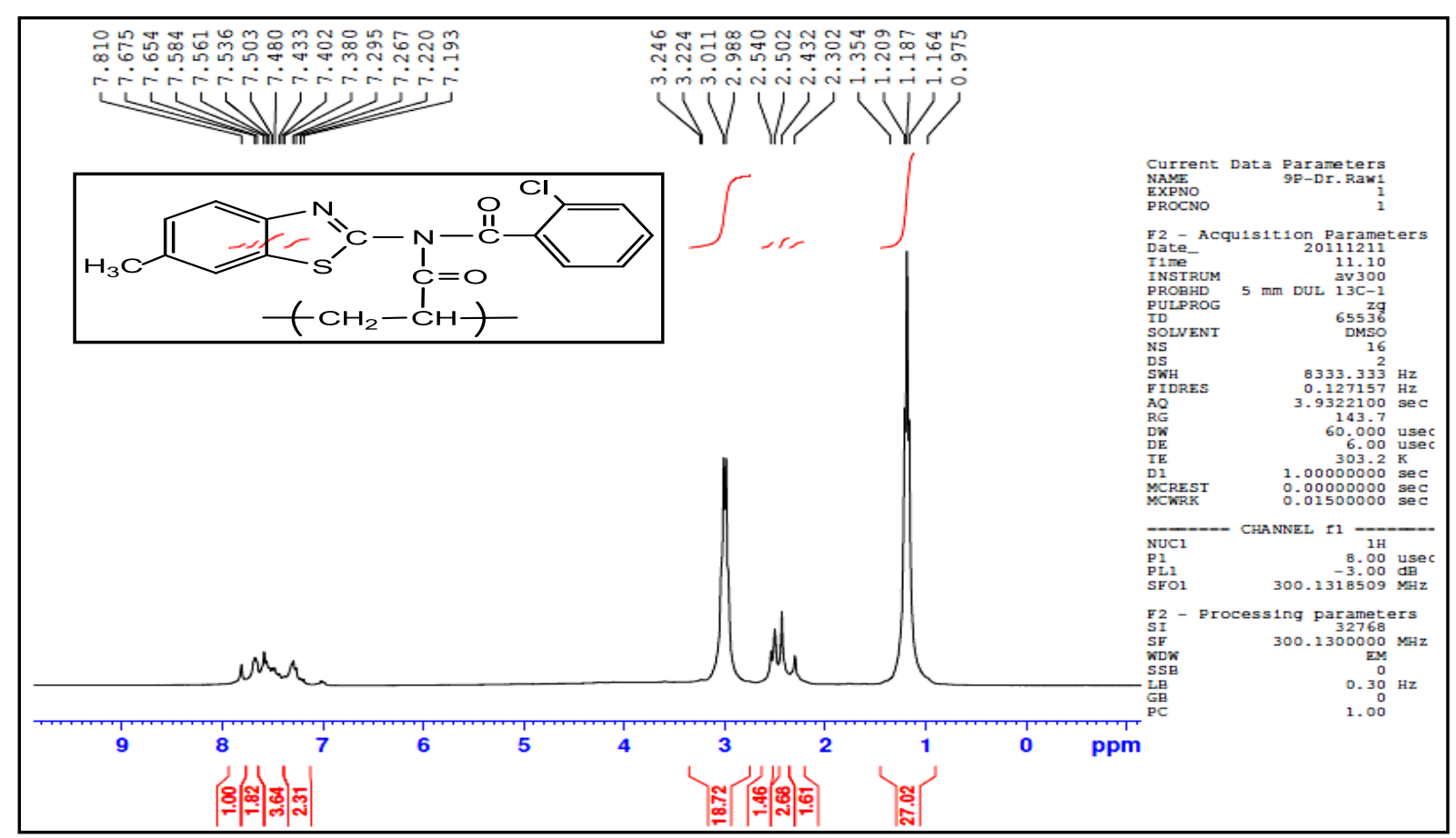

Fig.(3): ${ }^{1} \mathrm{H}-\mathrm{NMR}$ for compound[5] 
Table (4): UV spectra of the prepared heterocyclic polyimide

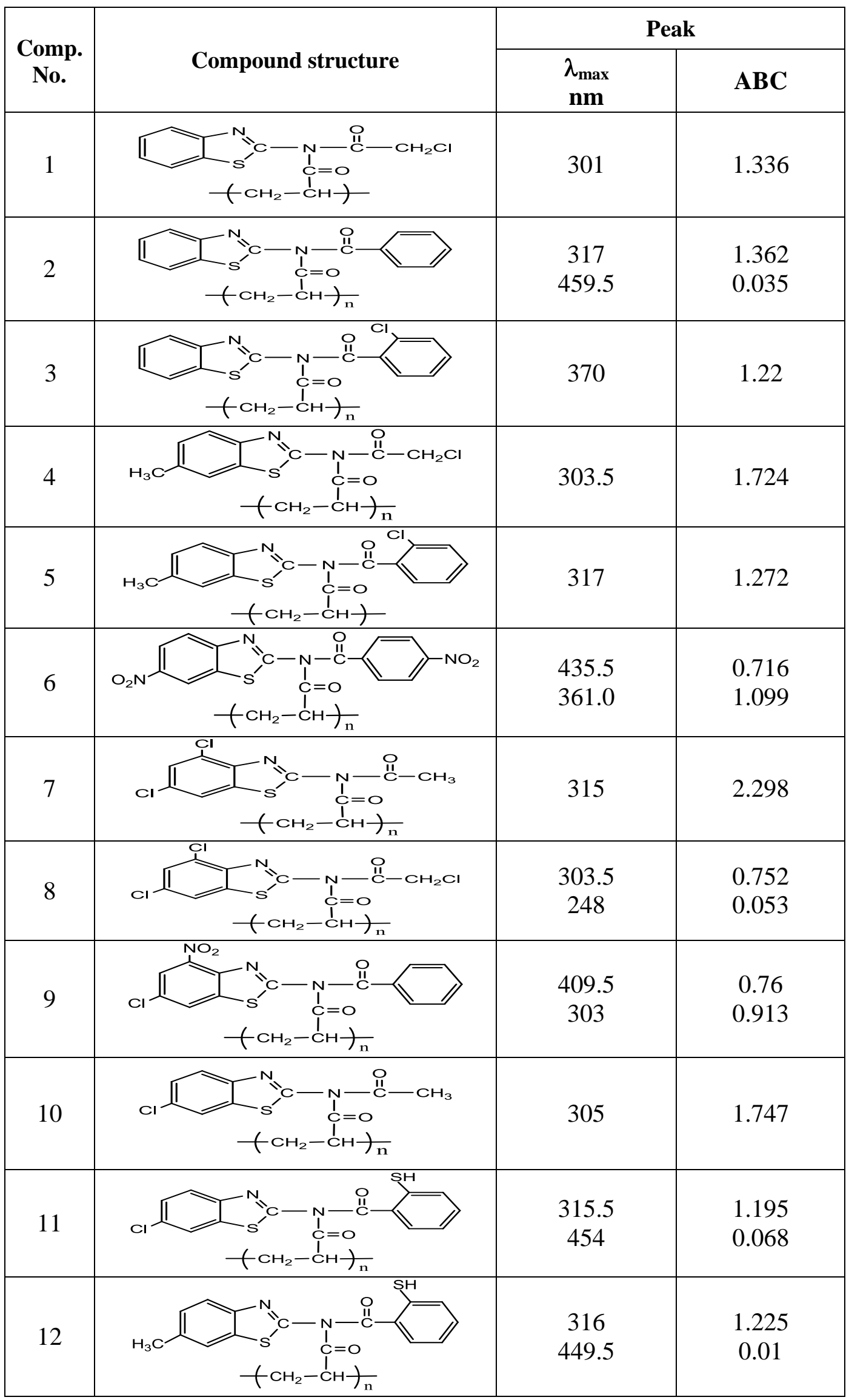


Table (5) : TG of some of the prepared poly heterocyclic imides

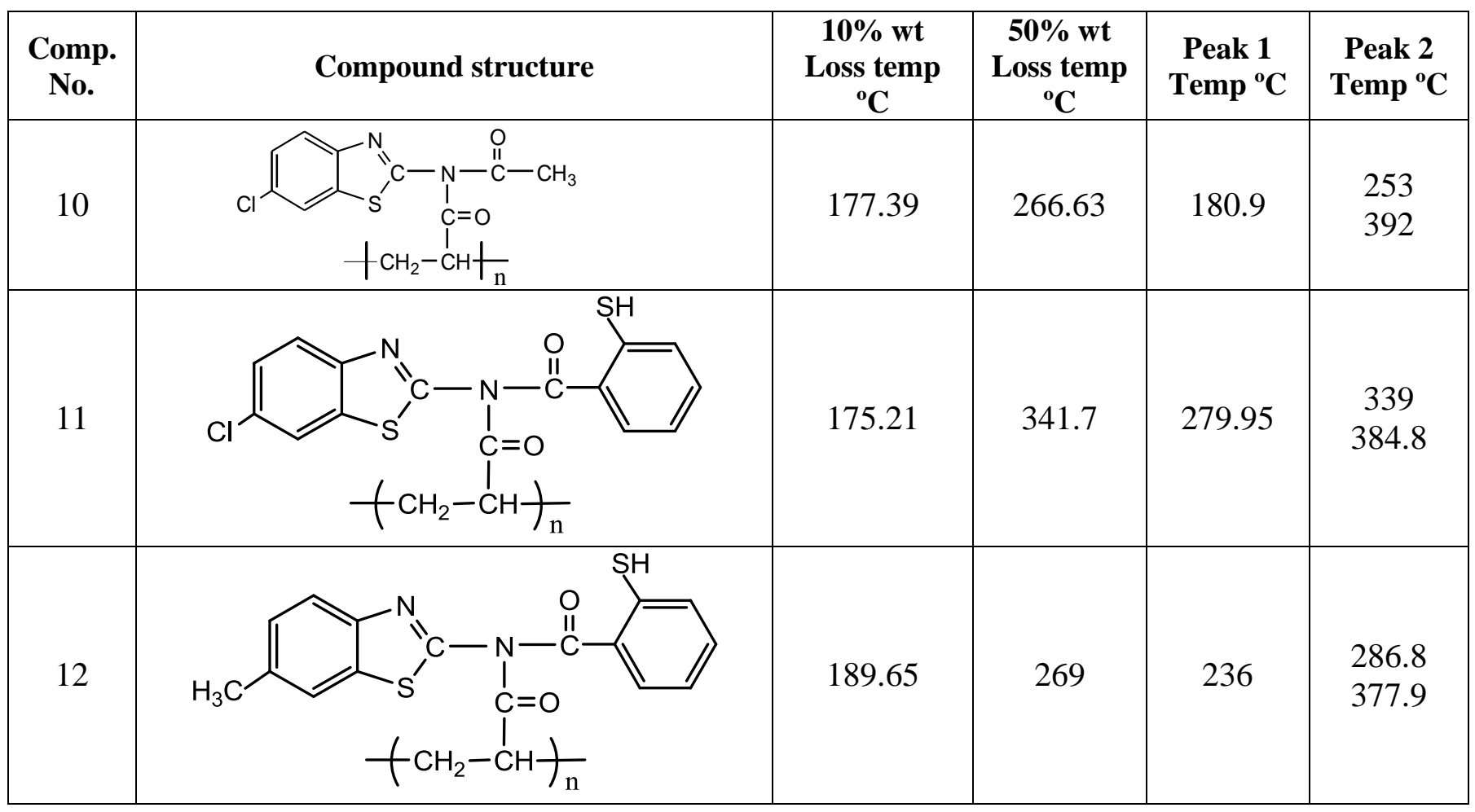

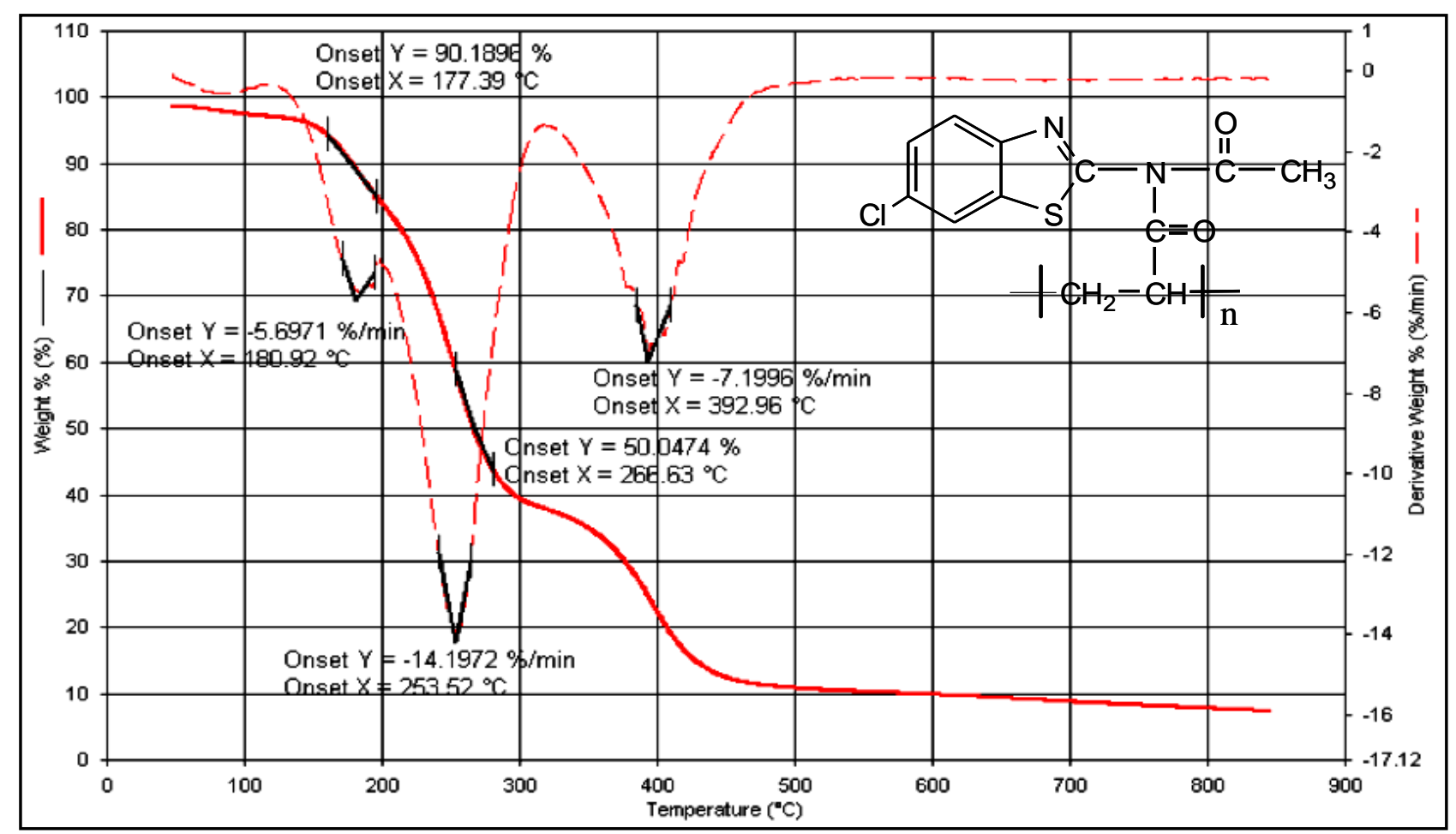

Fig.(4): TG for compound[10] 


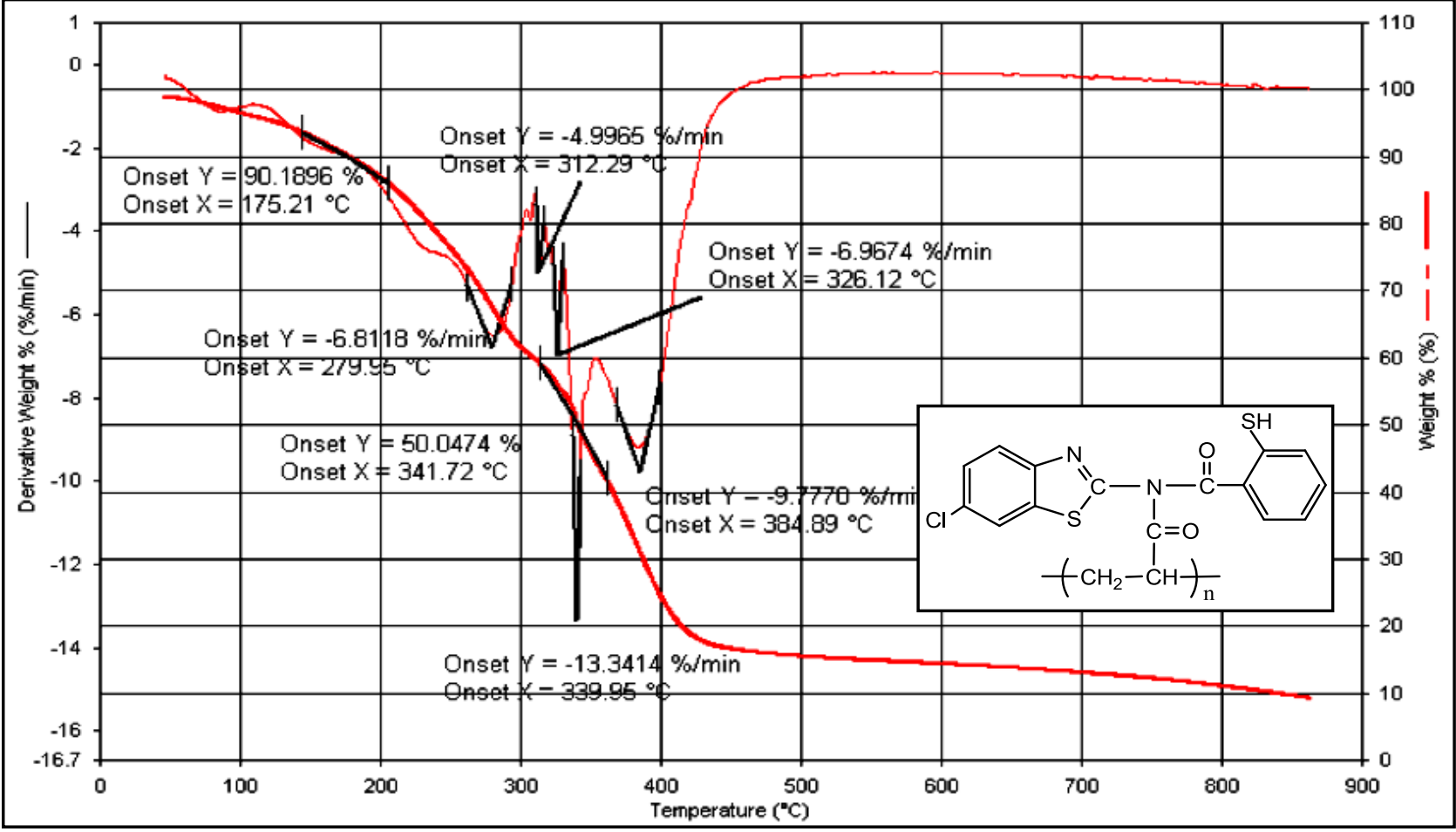

Fig.(5): TG for compound[11]

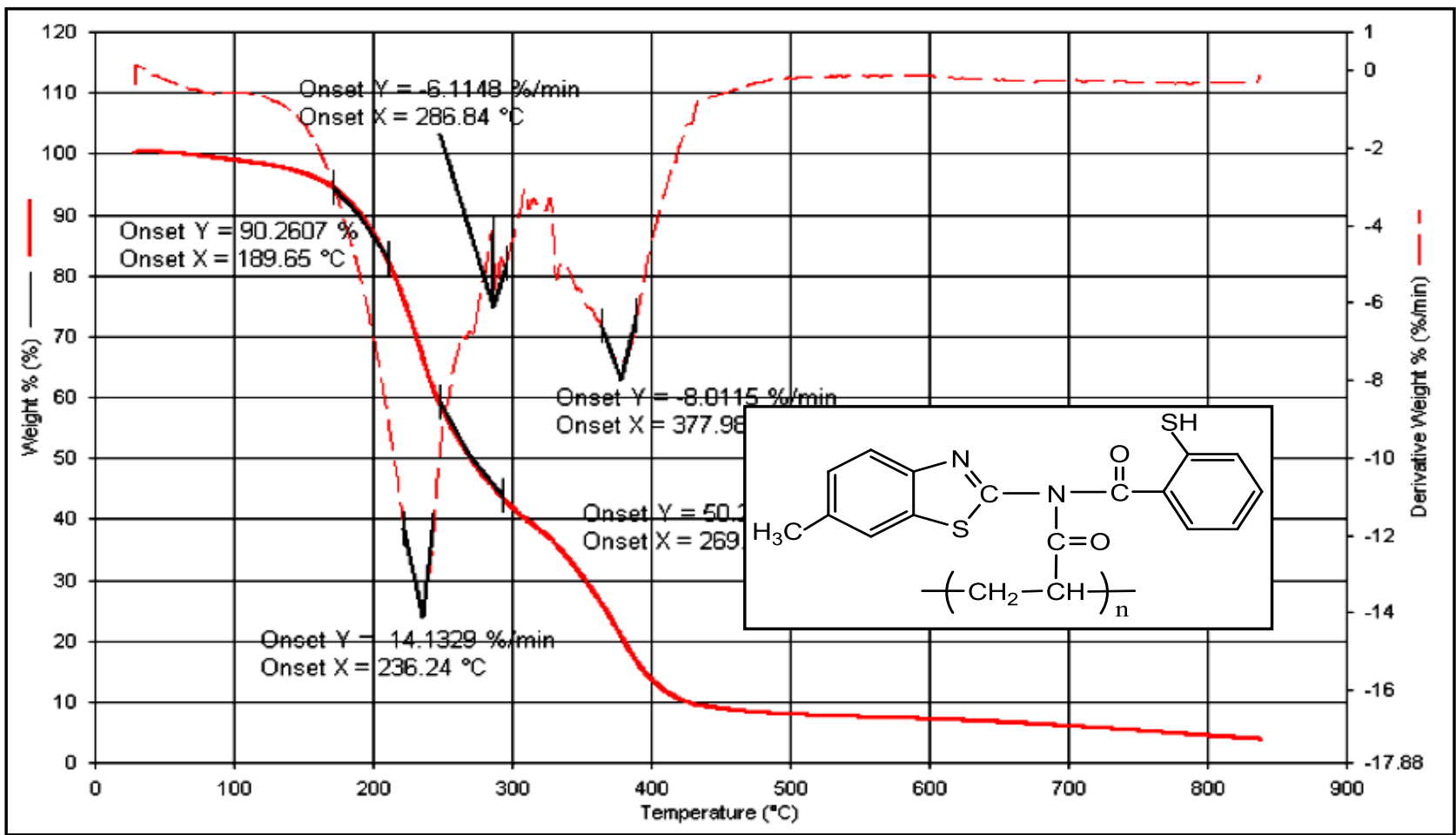

Fig.(6): TG for compound[12]

References 1. Yadav.P.S and Senthilkumar.D.G.P. 2011. 
"Benzothiazole:

Different methods of synthesis and diverse biological activities". IJPSDR., 3(1): 1-7.

2. Gupta.S, Ajmera,N. Gautam,N. Sharma.R. and Gautam.D. 2009. "Novel synthesis and biological activity study of pyrimido[2,1b]benzothiazoles". Ind. J. Chem., 48B: 853-858.

3. Kumbhare, R.M. Ingle.V.N. 2009. "Synthesis of novel benzothiazole and benzisoxazole functionalized unsymmetrical alkanes and study of their antimicrobial activity". Ind. J. Chem., 48B: 996-1000.

4. Muthi.Y, and Pathak.D. 2008"Synthesis and antimicrobial screening of substituted 2mercaptobenzothiazoles".J Pharm Res.7(3);153-155

5. Rajeeva,B, Srinivasulu.N. and Shantakumar.S 2009. "Synthesis and antimicrobial activity of some new 2-substituted benzothiazole derivatives. Ejournal of chemistry., 6(3): 775779.

6. Maharan.M . William.S . Ramzy.F and Sembel.A. 2007. "Synthesis and in vitro evaluation of new benzothiazole derivatives as schistosomicidal agents". Molecules., 12: 622633.

7. Kini S. Swain.S and Gandni.A 2007. "Synthesis and evaluation of novel benzothiazole derivates against human cervical cancer cell lines". Ind. J. Pharm. Sci., Jan-Feb: 46-50.

8. Stanton.H , Gambari.R, Chung.H.C, Johny.C, Filly.C, and Albert.S 2008. "Synthesis and anticancer activity of benzothiazole containing phthalimide on human carcinoma cell lines". Bioorg. Med. Chem., 16: 3626-3631.

9. Wang. M, Gao.M , Mock B, Miller.K, Siedge, G, Hutchins.G and Zheng.Q,2006. "Synthesis of $\mathrm{E}_{11}$ labelled flulorinated 2-aryl benzothiazoles as novel potential PET cancer imaging agent". Bioorg. Med. Chem.., 14: 85998607.

10. Gupta.S , Moorthi.N and Sanyal.U 2010. "Synthesis, cytotoxic, evaluation, in silico pharmaco kinetic and QSAR study of some benzothiazole derivatives". Ind. J. Pharmacy pharm. Sci., 2(3): 57-62.

11. Sreenivasa.M. Jaychand.E ShivakumarB, Jayrajkumar.K and

Vigaykumar.J.2005. "Synthesis of bioactive molecule flurobenzothiazole comprising potent heterocyclic moieties for anthelmintic activity". Ind. J. Chem., 44B: 2404-2408.

12. Pattan.S, Suresh.C, Pujar.V Reddy.V, Rasal.V and Koti.B 2005. "Synthesis and antidiabtic activity of 2-amino[5(4sulphonyl benzylidine)-2,4thiazolidine none]-7-chloro-6flouro benzothiazole. Ind. J. Chem., 44B: 2404-2408.

13. Omote.T. 1996."Polyimidefundametals and application". M. K. Ghosh and K. L. Mittal, Ed. Marcell Dekker. Inc, New York., p.121.

14. Bureau.J.M. and Mittal.J.P. 1996. "Applications of polyimides as photosensitive materials". M. K. Ghoh, K. L. Mittal. Marcel Dekker, New York., p.743.

15. Feger.C, Khojasteh.M.M and Grath.J.E. 1989. Polyimides materials chemistry and characterization amesterdam. Elsevier, 453-478. 
16. Wilson.D, Stenzenberger.H.D. and Hergenrother.P.M. 1990. "Polyimide". Glasgow, black., p.360-395.

17. Barikani.M. 2002. " Polyimides derived from diisocyanate". Iran. Polym. J., 11: 215-236.

18. Rozhanskii.I, Okuyama.K. and Goto.K. 2000. "Synthesis and properties of polyimides derived from isomeric biphenyl-tetra carboxylic dianhydrides". Polymer., 41: 7057-7065.

19. Der-jang L. Been-yang.L and Chia-wei.Y. 2001"Synthesis and characterization of new organosaluble polyimides based on flexible diamine".Polymer .,42:839-845.

20. Tamami.B. and Yeganeh.H. 2001. "Synthesis and characterization of novel aromatic polyimides derived from 4-aryl-2,6-bis(4- aminophenyl)pyridines". Polymer., 42: 415-420.

21. Hussain.S.M.2003. Ph.D. Thesis, College of Science, University of Baghdad.

22. Stuckwisch.C.G. 1949. J. Am. Chem. Soc., 71: 3417.

23. Mahdi.S.A.2008.M.Sc. Thesis, College of Science, University of Baghdad.

24. Carey.F.A and Sundber.R.J. 2007. "Advanced Organic Chemistry Part A: Structure and Mechanisms", $5^{\text {th }}$ Ed., New York.

25. Crews.P . Rodriguez.J and Jaspars.M. 1998. "Organic structure analysis", Oxford University Press, New York.

26. Korshak.U.V. 1969. "The Chemical structure and thermal characteristics of polymer".

27. Al-Farajy.G.H.A. 2003. M.Sc. Thesis, College of Science, University of Baghdad.

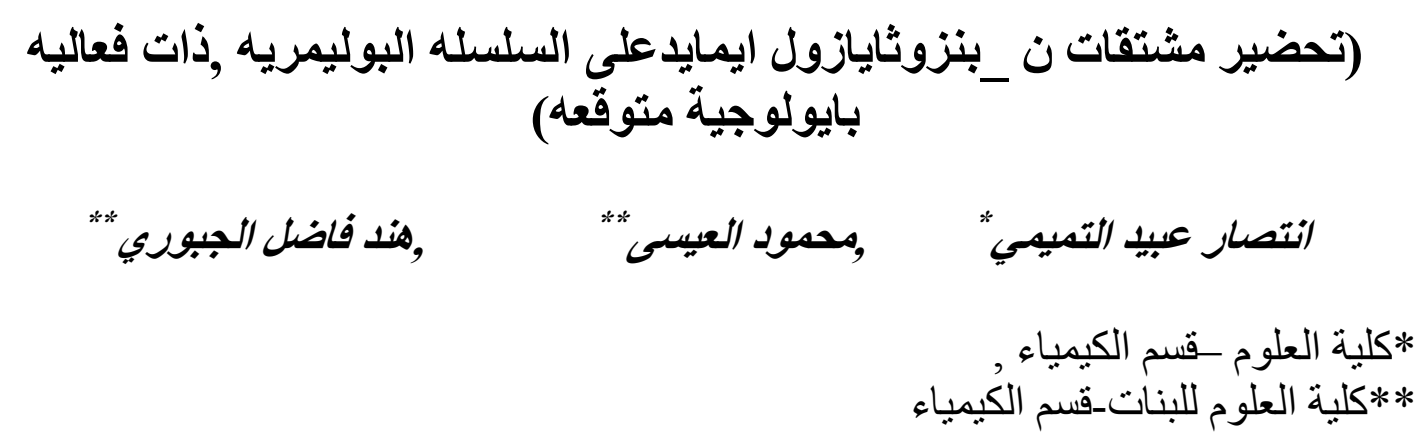

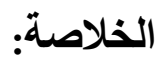

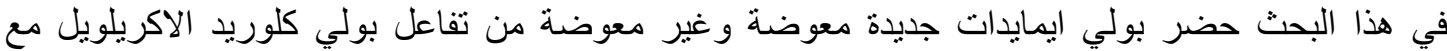

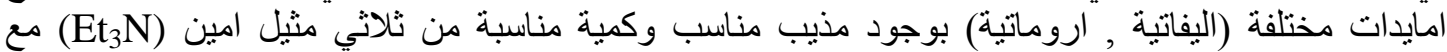

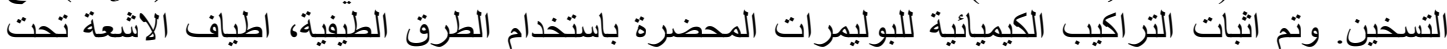

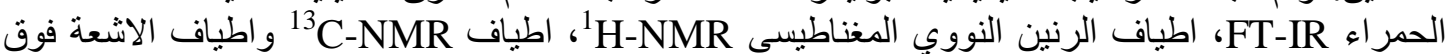

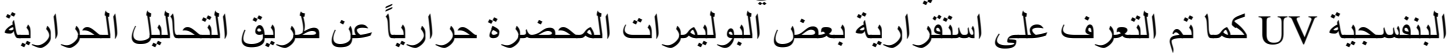

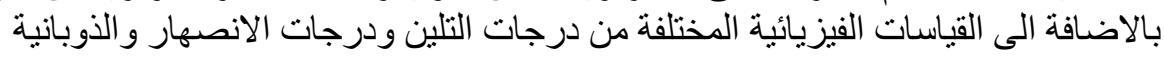

